\title{
LIST OF MAPS AND FIGURES
}

\section{Maps}

2.1 Adeebeba and its neighbours in the nineteenth century: I 37

2.2 Adecbeba and its neighbours in the nineteenth century: II 38

2.3 Adeebeba lands $\quad 47$

4.1 Asante and the Gold Coast in $1950 \quad 134$

5.1 The growth of Kumase 1800-2000 208

\section{Figures}

2.1 Sketch Plan of the sbosomfie of Adecbeba taa kwabena bena in 1945

2.2 Sketch of afua brahua and kramo from information supplied by Kwasi $\mathrm{Fi}$

2.3 'History of the descent of a Fetish. Kwabena of Adecbeba' 88

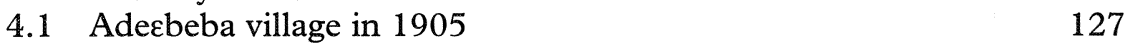

4.2 Roadmaking in Mampon, Asante about 1920

4.3 Sketch Map of Kumase in 1910 . 143

4.4 Colonial Kumase: Kagyatia in $1941 \quad 148$

4.5 Sketch Map of Kumase in $1950 \quad 160$

4.6 The Witchfinding cult of aberewa in Kumase in $1908 \quad 185$

4.7 The Famous 'witchfinder' bra kunde at Koforidua 188

4.8 Sketch of 'An Evil Attack' from a notebook kept by Kofi 191

4.9 'Graduate: University of hard knocks': J. C. Frimpong to M. Fortes, $1946 \quad 195$

4.10 'Sitting on the Fence' by J. C. Frimpong, 1945-6 196

5.1 Programme Cover, Kumase Town Planning Exhibition, 1945202

5.2 Present Realities: three views of Kumase in 1945 206-7

5.3 Future Possibilities: four planning sketches of Kumase by E. Maxwell Fry, 1945

Fragments I: incomplete sketch plan of Adeebeba in 1945
F.5 Fragments II: incomplete sketch map of Adeebeba farmland in 1945

5.6 Adeebeba today I: the Bekwai road at Adeebeba 220

5.7 Adeebeba today II: entrance to old Adeebeba village 221

5.8 Adeebeba today III: section of main street of old Adeebeba village 222

5.9 Adeebeba today IV: beauty parlour 223

5.10 Adeebeba today V: new house 223 